\title{
CONSUMERISM AND CONSUMERS IN BRAZIL
}

Gisela B. Taschner

This text addresses the issue of consumerism and some of its impacts on consumer culture and behavior, the structure of local markets, and the relationship between corporations and customers, in the case of Brazil.

It draws on some questions arisen from a comparative study on consumerism in Brazil, the USA and some Western European countries, carried out by the author previously (Taschner, 1995) and which is being updated presently.

\section{THE ISSUE OF CONSUMER PROTECTION}

The first steps toward consumer protection can be tracked back to the XIX century at least in the Western world. In some countries, beginning in society, in others within the state, the field of consumer protection developed during the first half of the $\mathrm{XX}$ century and consumerism reached its peak during the mid1960s in the USA, and in the early 1970s in European countries like France and Great Britain. After that, consumers were already rather well protected from a legal point of view; and I guess one could say that their rights were enforced by and large and came to be taken for granted in those countries. Thus consumerism ceased to be a national issue. Globalization brought up the economic blocks and the need to harmonize norms of partnercountries. And consumers strength came to be used on behalf of other social quests.

The development of consumer protection as a question is linked with the consolidation of capitalist mass production and consumption.

The geographical extension of the markets and the separation between the production and sales departments disclosed new problems related to packaging and to the use of conservers so that the products - perishable products in particular - should not deteriorate; also there is the question of misleading packages. The depersonalization of relationships in sales and purchase, and an unprecedented development of advertising left room for misleading messages and difficulties of communication; one might find nobody to complain to; perhaps the question of ethical responsibility had to be seen differently too. The complexity of use and the risks involved in products generated by an increasingly sophisticated technology entailed problems of safety and handling difficulties; the relatively higher cost of durable goods created expectations of durability which might not be fulfilled - these are some of the aspects connected with the development of consumers problems in mass production and mass consumption societies.

There are differences between different countries in the matter of consumer protection. Thus, in the 
First World, when concern with the consumer began to make itself felt, this happened in countries which had previously solved (in a better or worse manner, according to country) a series of social problems: absolute poverty, public health, basic education. These were affluent societies, with a broad spectrum of guaranteed social rights, a deeply rooted tradition of citizenship (in spite of the fact that the concept could be understood in different ways by each country), and a population which, for the most part, had no lack of the basic necessities for survival. During the peak of consumerism there, in the mid1960s and early 1970s (before the oil shock), the unemployment and foreign immigrants' situation had not yet assumed the problematic nature they would later (Taschner, 1995).

It should also be noticed that by and large consumerism rose together with the Welfare State and within a frame of social regulation (Bryner, 1990).

Furthermore, the rise of consumerism seems to have been connected with a change in social criticism in its broadest sense.

In fact, until the $1960 \mathrm{~s}$, social criticism of capitalism used to challenge society as a whole; from a particular moment on - it is difficult to say exactly when; perhaps May 1968 might be seen as a watershed in this respect - challenging society as a whole ran out of breath; in its place that society came to be accepted in principle as a fact and criticism was redirected towards specific aspects of the social life. Concern with an excess of technology, disenchantment with science and the search for a return to nature, for alternative knowledge, the search for a personal life-style, apart from the great mass, the attention paid to quality of living: these came to gain in importance (Naisbitt, 1982; Naisbitt and
Aburdene, 1990; Popcorn, 1991 captured some of those trends). It was in that process, as I see it, that the question of consumer protection acquired weight. This was also the case with other social movements, e.g. feminism and ecology.

Consumer protection would evolve differently below the Ecuador.
Defesa do Consumidor (Idec), the most successful of them, was created in 1987.

In 1988, Brazil received a new Constitution, to replace that of the dictatorship (from 1967). In 1990, a Code for Consumer Protection was approved by Congress, and on September 11, 1990, it received the

\section{The development of consumer protection as a question is linked with the consolidation of capitalist mass production and consumption.}

\section{CONSUMERISM IN BRAZIL}

The issue of consumer protection reached Brazil from the USA, at the beginning of the 1970s (rather later than it had reached Europe) in the midst of a process of an accelerated modernization, which took place as the country was industrialized. It first reached the media, in connection with the regulation of advertising. The first civil associations for consumer protection appeared, but they could not manage to take off.

At that time, the government of the state of São Paulo began to show some degree of concern for the consumer and in 1978 it created the State System for Consumer Protection in São Paulo. The executive branch of that system, hereinafter known as Procon, was the first one in Brazil. The São Paulo Procon became the benchmark for the equivalent organs which began to be set up in other states in the 1980s.

In 1978 the Code for selfregulation in Advertising was established by Conar (National Council for Self-Regulation in Advertising).

From 1982 on, still during the transition from authoritarianism to democracy some civil associations (NGOs) emerged. Instituto de sanction of President Collor as Law Nr. 8078. On March $11^{\text {th }} 1991$, the Code for Consumer Protection came into effect.

So it took almost 20 years for the issue of consumer protection to become a set of laws, since it arrived in Brazil as part of a process of radiation from the USA to the rest of the world. And as the Code for Consumer Protection was approved, another problem was disclosed, regarding its implementation.

This was probably because it met with a very special context here, perhaps also characteristic of some other countries of Latin America at the time.

In fact, in the early 1970 s, modernization had made the new problems consumers had to face quite real in Brazil: adulterated products, foodstuffs unsuitable for consumption due to unhygienic conditions of manufacture or the presence of toxic additives, fraudulent packaging, misleading publicity, defects in durable goods - these are only some examples.

And the paraphernalia of organs and disconnected laws available here previously resulted in overlapping authorities on the one hand, and big lacunae on the other, that made consumer protection ineffective. 
Also, a consumer culture was being built in society. But neither modernization nor affluence had generalized in Brazil when the issue of consumer protection was raised here; side by side with "affluent spots of modernity", many Brazilians still had to deal with problems like absolute poverty, illiteracy or undereducation, infant mortality, malnutrition, to name a few.

So consumers who could afford to consume were quite without protection. At the same time, for many other people, the right to consume was not assured. Consumer protection had a problem of legitimacy in its beginnings ${ }^{1}$. food and drugs) were immediately enforced. But other ones depended on support by other politicians (e.g. when they needed further regulation) or at least on customers awareness of their new rights. And that was a problem difficult to overcome.

\section{IMPACTS ON THE MARKET}

The characteristics of the evolution of consumer protection in Brazil - its belated beginning, during a process of rapid modernization by authoritarian means, the absence of a strong tradition of citizenship, a society

\section{The São Paulo Procon became the benchmark for the equivalent organs which began to be set up in other states in the 1980s.}

Besides, Brazilians had no tradition of participating in NGOs. The state used to be ahead of society as far as many social demands were concerned. And even in periods of formal democracy, citizenship had actually been rather restricted to the wealthy here. In the 1970 s it was further challenged by Brazil's authoritarian regime, which restricted seriously the freedom of speech and association. No wonder it took long for Brazil to have a Consumer Protection Code!

Last but not least, when the issue of consumer protection finally became a set of laws (a very good one, experts say), it bumped into another trend that was rising in Brazil: neo-liberalism. And that made consumerism lose its punch within the state apparel and among politicians.

So when the Code was ready, some of its parts that were selfapplicable (e.g. validity dates in which is non affluent as a whole, the presence of a large number of social questions which were not resolved with industrialization, the form of articulation between state and civil society, and between the rise of the consumer issue and the process of regulation of society by the state have all made consumer protection more complex here as compared with some First World countries.

In Brazil the issue of consumer protection belongs in a reality where problems of the past and of the future have got interwoven and demand to be solved all at the same time. This entails a specific configuration of the arena where companies act.

Brazilian Consumer Protection Code is said to be a very advanced one. The state has made it, walking ahead of civil society. There was no social movement preceding it, except inside one sector of the state apparatus. Awareness of consumers rights has not evenly spread up among the Brazilian population, even after the advent of the Code.

The state is rather swift to enforce the law against those who transgress the Code. Yet it has not used resources enough to make the best use of it, especially in preventive aspects such as consumer education. The enforcement of the Code by the state agencies bumped into the neoliberal social deregulation trends.

Corporations have reacted differently to the Code. There was a long negotiation between the government and the private sector in the early nineties before some norms of the Code could be enforced. The multinational companies started to apply them first, as they already had know-how from other markets in which they were present.

As the Code forces corporations to "listen to the customers and solve problems inherent in the goods acquired", many companies - starting again by multinational ones - have established Customer Services in their organizations; actually some of them had created that service before the Code was made. The number of Customer Services (or SACs as they are known in Portuguese) rose from 50 in 1991 to 3,000 in 1997 , according to Lazzarini (1997).

Although they were doing nothing else than obey the law, some companies started to use their Customer Services as a competitive differential, advertising them in the media - under a banner somewhat like "we care about our customers".

But the Customer Services were not equally organized in all companies (Zulzke, 1990). Some of them were (and still are) just decorative pieces and customers who looked for them ended up at the Procon in order to get their problems solved. Others were put to work high in the organization hierarchy, in the frame of a consumer focussed 
marketing and thus it is possible that some private corporations have been helping to implement consumers rights in Brazil.

In that direction, a national association of professionals who work for Customers Services of private companies, Secanp ${ }^{2}$, was created in 1989 as an NGO. Its mission, as stated in the Secanp site in the Internet, is to bring quality to both the consumer and the corporation, by living up to customers expectations and needs and by assuring competitiveness and higher profitability to the private companies.

As Customer Services became routinized, more consumers have become aware of and attentive to their rights. That fact was probably reinforced by the control of inflation by Brazilian government through the creation of a strong currency, in mid-1994 which made the income distribution slightly better. In absolute numbers that meant a rather big increase of income in the hands of lower strata and hence a change in their consuming quantities and patterns. Electro-electronics, for example, had a sales boom then and that led to new problems and thus to a deeper sensibility regarding consumers rights and needs among lower strata consumers.

But this sensibility is not smoothly spread in the Brazilian market either. It is much more accurate, for example, in some urban-upper-middle-class segments, which lead life-styles more similar to First World countries standards and who are more "world aware" as they often travel abroad (or did so before the Brazilian currency was devaluated in 1999). For market segments within those middle classes, "obeying the Code" is not enough as a competitive differential. Selling biodegradable detergents, recycled paper, low fat food may be a good one, though, as well as sponsoring cultural events or doing some types of social marketing.
Anyhow, the development of consumer consciousness is still in course in Brazil. According to the target, the company has to deal in a very different way with the question of consumers expectations.

Last but not least, the opening of Brazilian economy to international markets since the early 1990s in the context of the process of globalization may have been a critical factor for the generalization of consumer consciousness.

Globalization has brought both the consumer protection issue and new multinational corporations to Brazil. And as it goes on, aside from other dimensions ${ }^{3}$, it seems to have a double effect.

At a regional level, particularly in the Mercosur, Brazil has been facing the problem - already faced by the USA and the European Community - of harmonizing norms of our Code with the ones of other countrymembers. That harmonization has been rather complicated as consumer protection seems to be more advanced in Brazil than in other fellow countries of South America: in some of them (e.g. Chile, Uruguay, Argentina) consumer protection is weaker than in Brazil and in others there was no protective legislation at all (e.g. in Paraguay). The devaluation of Brazilian currency has made it even more difficult.

As for the domestic market, global competition has had a very strong impact on the Brazilian consumers points of view as they have had a wider spectrum of choice as well as the opportunity to compare domestic made goods to foreign made similar ones; and many of the latter have proven to be less expensive and of better quality than Brazilian ones.

So, the existence of an advanced Code in Brazil - with its society split in so different segments, some of them "all globalized" and others who are barely reached by the right to consume, (but already touched by consumer culture) and where citizenship is still being built - has opened up possibilities for the private sector to treat consumers better than before (in different manners according to the targets) and to use that as a competitive differential, as globalization increases competition.

By doing that, private corporations will be not only investing on their image and positioning themselves better in the market. They will be also contributing to the building of a better society for everybody.

\section{REFERENCES}

BRYNER, Gary. La protection du consommateur aux etatsunis: naissance et déclin de l'approche réglementaire. Revue Française d'Administration Publique, nr. 56, p. 591 603, Oct./Dec. 1990.

LAZZARINI, Marilena. O movimento dos consumidores no Brasil. In: SEMINÁRIO INTERNACIONAL: O CONSUMIDOR NO CONTEXTO DA GLOBALIZAÇÃO. São Paulo : Insituto de Defesa do Consumidor (Idec), jul. 1997.

NAISBITT, John. Megatrends. New York : Warner Booksp, 1982.

ABURDENE, Patricia. Megatrends 2000. New York : William Morrow \& Co., 1990.

POPCORN, Faith. The Popcorn report. New York Doubleday, 1991.

SECANP. Available from Intemet: <http:// www.secanp.com. br> TASCHNER, Gisela B. Proteção do consumidor - um estudo comparativo internacional. São Paulo : EAESP-FGV/NPP, 1995. (Série Relatórios de Pesquisa, ํำ1/95).

ZULZKE, Maria Lucia. Abrindo a empresa para 0 consumidor. Rio de Janeiro : Qualitymark, 1990.

NOTES

This text is part of a bigger work still in progress; a firs version of it was presented at the Cladea 1997, XXXII Annual Assembly, Oct. 8-10, Monterrey, Mexico.

1. Cf. Maria Inês Fornazzaro, Chair of SP Procon and one of its oldest members, reported, apud Taschner (1995).

2. I would like to thank Cíntia M. Araujo for gathering relevant information about Secanp and Idec for this article.

3. There are several other dimensions of globalization which are obviously very important, e.g. financial ones, but they are out of the scope of this paper.

Gisela B. Taschner is Professor at EAESP/FGV. E-mail: gtaschner@fgvsp.br 